\title{
A trial of phosphohexose isomerase as a means of detecting cervical carcinoma
}

\author{
GRAINGER G. MUIR AND GAJUTE J. VALTERIS \\ From the Department of Clinical Biochemistry, Luton and Dunstable Hospital, Luton, Beds.
}

SYNOPSIS Phosphohexose isomerase activity has been studied in a well women's clinic with a automated method. In this series, in which freeze drying was used, the assay was not a reliable screening technique, as it was found that the method caused considerable loss of enzyme activity.

In a previous paper (Muir, 1966), the possibility of using phosphohexose isomerase as a screen test for cervical carcinoma in situ and invasive carcinoma was suggested. It was felt that the activity of this enzyme in the vaginal fluid might provide a means of selecting those cases which were more likely to have cervical carcinoma, and therefore the number of smears needing examination would be considerably reduced. Since all six cases of carcinoma in situ reported in the previous paper were detected, it appeared to be worth while making a trial of such an approach. In the previous paper a manual technique (Bodansky, 1954) had been used. In this paper a Technicon AutoAnalyzer assay was used and the results are expressed as a function of dry weight or potassium concentration. In a number of samples the effect of freeze drying has been investigated.

\section{MATERIALS}

Samples were obtained from the local authority cytology clinic at Luton and the gynaecological departments of the Luton and Dunstable and Bedford General Hospitals.

\section{METHODS}

Samples were collected and prepared in a similar manner to that of Bonham and Gibbs (1962). After freeze drying they were reconstituted to $10 \mathrm{mg}$. dry weight per $\mathrm{ml}$. of distilled water. The assay used for phosphohexose isomerase was a modified version of that described by Schwartz, Kessler, and Bodansky (1960). The substrate concentration was altered to $0.008 \mathrm{M}$ glucose-6-phosphate to obtain linearity. Since the colour reagents in the Bodansky assay are highly viscous and in samples with low enzyme activity the pattern is not very satisfactory, the colour reagent of Horrocks, Ward, and King (1963) was used. The vaginal fluid extract was diluted 1 in 10

Received for publication 26 July 1967. with saline for the assay. It did not prove necessary to runblanks.

Potassium was estimated on the Eel flame photomete using 1 in 20 dilution in which $0.1 \mathrm{ml}$. of the vaginal fluid extract was diluted to $2 \cdot 0 \mathrm{ml}$.

\section{CALCULATION OF RESULTS}

The sample line removes $0.53 \mathrm{ml}$. from each sample cup and the concentration of vaginal fluid extract in the cups is $1 \mathrm{mg} . / \mathrm{ml}$., thus phosphohexose isomerase activity of $0.53 \mathrm{mg}$. of the vaginal debris is assayed.

The phosphohexose activity in $\mu$ moles $/ \mathrm{min} . / \mathrm{g}$. dro weight

$$
=\frac{\mu \text { moles } / \mathrm{min} .}{0.53} \times 1,000
$$

The potassium content is in milliequivalents per $0.1 \mathrm{~mL}$ or per $1 \mathrm{mg}$. of vaginal debris. The micromoles of fructose formed per minute divided by $0.53 \mathrm{mg}$. gives the enzymeactivity per $1 \mathrm{mg}$. of vaginal debris. If this activity is. divided by the potassium concentration per milligrang the activity is expressed per milliequivalent of potassium in vaginal fluid.

Phosphohexose isomerase activity per milliequivalen $\stackrel{ }{\bar{P}}$ of potassium

$$
=\frac{\mu \mathrm{moles} / \mathrm{min} .}{0.53} \times \frac{1}{\text { potassium concentration }}
$$

RESULTS

The original paper was based on a manual metho using a substrate concentration which did not give् linearity and used a longer incubation time, thus thẹ? results of the two methods are not comparable, the automated method giving higher results.

RESULTS PER GRAM DRY WEIGHT These are given iri⿱乛龰 Table I. Of 51 normal women, $38(75 \%)$ had activities of less than $15 \mu$ moles per minute per gram, $41(80 \%$ 
T A B L E 1

PHOSPHOHEXOSE ISOMERASE ACTIVITY IN VAGINAL FLUID SAMPLES FROM VARIOUS GROUPS OF WOMEN

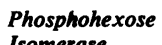

\begin{tabular}{|c|c|c|c|c|c|c|c|c|}
\hline $\begin{array}{l}\text { Isomerase } \\
\text { Activity ( } \text { moles } \\
\text { per min. } \\
\text { per } \mathrm{g} . \text { ) }\end{array}$ & $\begin{array}{l}\text { Normal } \\
\text { Women }\end{array}$ & $\begin{array}{l}\text { Well } \\
\text { Women }\end{array}$ & $\begin{array}{l}\text { Postmeno- } \\
\text { pausal } \\
\text { Women }\end{array}$ & $\begin{array}{l}\text { Pregnant } \\
\text { Women }\end{array}$ & $\begin{array}{l}\text { Gynaecol- } \\
\text { ogical } \\
\text { Lesions }\end{array}$ & $\begin{array}{l}\text { Carcinoma } \\
\text { in situ }\end{array}$ & $\begin{array}{l}\text { Invasive } \\
\text { Carcinoma }\end{array}$ & $\begin{array}{l}\text { Carcinoma } \\
\text { of Body }\end{array}$ \\
\hline Total & 51 & 288 & 9 & 19 & 584 & 12 & 43 & 9 \\
\hline
\end{tabular}

had levels below $20 \mu$ moles/min./gram. When cases with activities greater than $15 \mu$ moles were regarded as suspicious, $45 \%$ of cytology clinic patients required a smear and $48 \%$ of patients attending the gynaecological clinic. At $20 \mu$ moles per minute per gram the incidence of suspicious cases fell in the respective clinics to 33 and $42 \%$. At both 15 and $20 \mu$ moles a number of cases of carcinoma in situ and invasive carcinoma were missed. The figures were five of 12 cases with carcinoma in situ and two of 43 cases with invasive carcinoma at $15 \mu$ moles, while at $20 \mu$ moles the figures were eight and seven.

RESULTS PER MILLIEQUIVALENT OF POTASSIUM These are shown in Table II. Eight of nine normal women had activity below $0.15 \mu \mathrm{moles} / \mathrm{min}$./milliequivalent. In a gynaecological clinic, 36 of 79 had lower levels (45\%). In the samples from the well women's clinic, 173 of 248 cases $(70 \%)$ had levels below $0.15 \mu$ moles/ $\mathrm{min}$./milliequivalent. Using this level, one of four

\section{T A B L E I I}

PHOSPHOHEXOSE ISOMERASE ACTIVITY IN VAGINAL FLUID SAMPLE FROM VARIOUS GROUPS OF WOMEN

\begin{tabular}{|c|c|c|c|c|c|}
\hline \multirow{2}{*}{$\begin{array}{l}\text { Phosphohexose } \\
\text { Isomerase } \\
\text { Activity } \\
\text { (micromoles/ } \\
\text { min./ } \\
\text { mEq.) }\end{array}$} & \multicolumn{5}{|c|}{ Groups of Patients } \\
\hline & Normal & $\begin{array}{l}\text { Well } \\
\text { Women }\end{array}$ & $\begin{array}{l}\text { Gynaecol- } \\
\text { ogical } \\
\text { Cases }\end{array}$ & $\begin{array}{l}\text { Carcinoma } \\
\text { in situ }\end{array}$ & $\begin{array}{l}\text { Invasive } \\
\text { Carcinoma }\end{array}$ \\
\hline 0.50 or more & - & 17 & 8 & - & 2 \\
\hline $0.40-0.50$ & - & 14 & 5 & 1 & 3 \\
\hline $0.30-0.40$ & - & 14 & 16 & 2 & 4 \\
\hline $0.25-0.30$ & - & 10 & 4 & - & 1 \\
\hline $0.20-0.25$ & - & 10 & 3 & - & - \\
\hline $0.15-0.20$ & 1 & 13 & 7 & - & 3 \\
\hline $0 \cdot 10-0 \cdot 15$ & 1 & 25 & 4 & - & 1 \\
\hline $0.05-0.10$ & 2 & 87 & 12 & 1 & - \\
\hline up to 0.05 & 5 & 59 & 20 & - & - \\
\hline Total & 9 & 248 & 79 & 4 & 14 \\
\hline Under 0.15 & 8 & 173 & 36 & - & 1 \\
\hline
\end{tabular}

cases of carcinoma in situ was missed and one of 22 of invasive cervical carcinoma.

Freeze drying was investigated by mixing samples on a Rotamixer ${ }^{1}$ and then splitting them into halves. One half was assayed without any further treatment and the other freeze dried and reconstituted to its original volume. The potassium concentration was measured on both samples and the results were calculated on this basis. The results are shown in Table III. Freeze drying caused a considerable loss of phosphohexose isomerase activity.

\section{T A B L E I I I}

EFFECTS OF FREEZE DRYING ON PHOSPHOHEXOSE ISOMERASE

Phosphohexose Isomerase Activity (umoles/min./mEq. potassium)

\begin{tabular}{cc}
\hline Samples Not Freeze Dried & Samples Freeze Dried \\
\hline 0.202 & 0.007 \\
1.95 & 0.87 \\
0.303 & 0.03 \\
0.86 & 0.55 \\
0.11 & 0.003 \\
0.167 & 0.16 \\
0.175 & 0.178 \\
0.174 & 0.053 \\
0.674 & 0.433 \\
0.91 & 0.675 \\
0.62 & 0.079 \\
1.02 & 0.88 \\
0.33 & 0.217 \\
2.0 & 1.08
\end{tabular}

DISCUSSION

It was originally felt that in situ and invasive carcinoma of the cervix induced an inflammatory reaction in the cervical and vaginal tissue. Work on 6-phosphogluconate dehydrogenase supported such a concept (Muir and Canti, 1966). It appeared that phosphohexose isomerase was more markedly affected than 6-phosphogluconate dehydrogenase by

${ }^{1}$ Hock \& Tucker 
inflammatory changes (Muir, 1966) and would thus be a more sensitive indicator of gynaecological inflammatory lesions. It was hoped that phosphohexose isomerase might thus act as an initial screening test for detecting gynaecological lesions, amongst which would be carcinoma of the cervix. Unfortunately, phosphohexose isomerase activity does not appear to provide a means of screening for carcinoma in situ. The use of potassium as a means of expressing the activity did not improve the results. Certain cases of carcinoma in situ had very high enzyme activities which were considerably higher than others in situ. Invasive carcinomata are associated more commonly with high enzyme activity than benign lesions. When the results were expressed on a dry weight basis 30 of $43(70 \%)$ had activities greater than $50 \mu$ moles per minute per gram, while only $20 \%$ of patients with gynaecological lesions and $16 \%$ of women attending the cytology clinic had such levels. Of 12 carcinomata in situ, four had such levels. On a potassium basis similar results were found. The significance of such high levels in certain cases of carcinoma in situ may be fortuitous or else related to the natural history of the lesions. Freeze drying causes considerable loss of phosphohexose isomerase activity, but it is응 difficult to estimate how much the failure of the enzyme to detect cervical carcinoma can be? attributed to the use of freeze drying. Obviously? freeze drying should be replaced by other lysing agents to liberate the enzyme from the debris and? the enzyme activity expressed as function of anothero parameter such as potassium (Labrum, Gibbs, and Stagg, 1967).

It is a pleasure to acknowledge the kindness of Dr. R. M. Dykes, Medical Officer of Health, County Borougho of Luton, and his staff, in allowing us to obtain specimenso from their cytology clinics.

This work was supported by a grant from the British Empire Cancer Campaign and the North West Metropolitan Hospital Board.

\section{REFERENCES}

Bodansky, O. (1954). Cancer, (Philad.), 7, 1191.

Bonham, D. G., and Gibbs, D. F. (1962). Brit. med. J., $2,823$.

Horrocks, J. E., Ward, J., and King, J. (1963). J. clin. Path., 16, $248 \frac{\mathrm{n}}{\mathrm{D}}$

Labrum, A. H., Gibbs, D. F., and Stagg, B. H. (1967). A.R. Brit. Emp Cancer Campgn, 1966, part II, p. 173

Muir G. G. (1966). J. clin. Path., 19, 378.

$\longrightarrow$, and Canti, G. (1966). J. Obstet. Gynaec. Brit. Cwlth, 73, 611. Schwartz, M. K., Kessler, G., and Bodansky, O. (1960). Ann. N.Y. Acad. Sci., 87, 616. 